\title{
Selling water for the environment: how sustainable is it for irrigators?
}

\author{
S. Wheeler ${ }^{1}$, A. Zuo ${ }^{1}$ \& H. Bjornlund ${ }^{1,2}$ \\ ${ }^{1}$ Centre for Regulation and Market Analysis, School of Commerce, \\ University of South Australia, Australia \\ ${ }^{2}$ Economics Department, University of Lethbridge, Canada
}

\begin{abstract}
Up to one fifth of all irrigators in the Murray-Darling Basin had sold water entitlements to the Australian Government's Restoring the Balance program by 2012. The sale of water entitlements can have many direct and indirect consequences for irrigators, irrigator organisations, tourism, rural communities and the environment. This study specifically focuses on the consequences for irrigators, and provides an overview of the reasons why farmers sell water, and fluctuations in water use by irrigators over time. It predicts that, on average, irrigators that have sold water to the Australian Government in the southern Murray-Darling Basin have sold all their surplus water. As a consequence, without further water management or farm changes, they are likely to face water shortages three to four years every decade in the future.

Keywords: water entitlements, Australia, irrigators, water use.
\end{abstract}

\section{Introduction}

Since the early 2000s, irrigators in the Murray-Darling Basin (MDB) in Australia have faced considerable pressure in dealing with reduced water allocations, higher temperatures, reduced rainfall and falling commodity prices. In South Australia (SA), irrigators who were accustomed to receiving $100 \%$ of their high security water entitlements had to cope with less than one-fifth of their entitlements in one season in 2008-09, while irrigators in Victoria had to manage with one-third of their entitlement.

The severe drought and the lack of water flows in the River Murray contributed to already increasing environmental degradation. The inability of the 
states to resolve these problems led the Australian Government to commit $\$ 3.1$ billion in 2007 to the Restoring the Balance program, as part of the broader Water for the Future program, worth $\$ 12$ billion. Water was to be acquired for the environment between 2007-08 and 2016-17. In addition, in 2010-11 the Australian Government allocated additional funding of up to $\$ 310$ million per annum from 2014-15 onwards to bridge any remaining gap between the level of water returned to the MDB under existing Water for the Future initiatives, and the level required to be returned under the final MDB Plan [1]. The current goal is to return 2,750 GL of long-term average annual yield (LTAAY) to the environment from consumptive use, and currently the Australian Government has purchased 1,090 GL LTAAY from willing sellers, as at 31 July 2012 [2].

Cheesman and Wheeler [1] estimated that by the end of 2011 3,150 irrigators had sold water to the Australian Government. Some irrigators had sold water more than once. The Australian Bureau of Statistics (ABS) [3] estimated that there were 15,347 irrigators in the MDB, which suggests that up to $20 \%$ of irrigators have sold water to the Australian Government. Of the irrigators that had successfully sold water to the Restoring the Balance program, $60 \%$ had sold part of their water entitlement and were still farming, 30\% had sold all of their water entitlement and had exited farming, and $10 \%$ had sold all of their water and were still farming (either because they: converted to dryland farming only, or purchased water allocations, or were using groundwater entitlements, or had repurchased surface water entitlements).

\subsection{Community consequences from selling water}

There are many costs and benefits that must be considered in the evaluation of any effects from a reallocation of water from consumptive to environmental use and, in particular, irrigators selling water entitlements to the government to be used for the environment. Some of the issues that communities are concerned about include farm exit, population decline, reduced gross regional product, and job availability. Irrigation organisations are worried about irrigator exit from the system, causing a 'Swiss cheese effect'. The term 'Swiss cheese effect' refers to what happens when some entitlement holders along an irrigation channel sell their entitlements and stop irrigating, creating holes in the system, and reducing the efficiency of delivering water down that channel, stranding assets, and increasing the maintenance costs and delivery fees for remaining entitlement holders [4]. However, Cheesman and Wheeler [1] found that of the farmers who owned water in irrigation systems, $60 \%$ of those who sold water kept their delivery right. Most of these farmers did so because they were continuing to farm ( $94 \%$ of those still farming kept their delivery rights). Termination fees paid by exiting farmers are also meant to bring about a decrease in the costs faced by irrigation organisations, though it is clear that further investigation on the implications of selling water from various channels for many irrigation districts is needed.

Various economic modelling of the consequences of reallocating water suggest that a reallocation of between 3,000 to 4,000 GL may reduce irrigated agricultural output by between 10 to $17 \%$ [5]. Overall, agricultural output is 
estimated to decline by less than this for irrigated agriculture, because it is estimated that resources would shift out of irrigated agriculture to dryland agriculture. Employment effects across the Basin are likely to be negligible in the long-term, however there may be substantial short-term effects of job losses in particular communities [6, 4]. However, further studies are needed on the long-term structural changes in rural communities, such as how shifts in water and agricultural policy play a part in regional farm exit choices over time.

This paper is unable to fully investigate the community aspects of selling water for the environment, and focuses solely on a broad understanding of how selling water entitlements may impact irrigators in the future.

\subsection{Irrigator reasons for selling water}

As discussed extensively in Bjornlund et al. [7], farm debt is the main reason irrigators have sold water entitlements in the market historically, and the main reason they sell water to the government. Irrigator surveys from the 1990s to 2010 have found this to be the case. A large-scale survey [1] of water entitlement sellers asked farmers why they sold water (see Table 1). $29 \%$ of respondents cited the need to reduce debt as their prime reason for selling water. For those who were not exiting farming, over a third of them sold water for debt reasons. The other main reason offered by a quarter of respondents, that was similar to the farm debt reason, was that they needed to improve farm income and the viability of their farm, as a result of very low income in recent years. Ten percent of irrigators who sold water cited having surplus water to farming requirements as their main reason for selling water to Australian Government, with $13 \%$ of those

Table 1: $\quad$ Main reasons cited for water sales (or offer).

\begin{tabular}{|l|c|c|c|c|c|}
\hline & $\begin{array}{c}\text { No sale } \\
\text { or sale } \\
\text { held up }\end{array}$ & $\begin{array}{c}\text { Sold some } \\
\text { water still } \\
\text { farming }\end{array}$ & $\begin{array}{c}\text { Sold all } \\
\text { water still } \\
\text { farming }\end{array}$ & $\begin{array}{c}\text { Sold all } \\
\text { vater and left } \\
\text { farming }\end{array}$ & $\begin{array}{c}\text { Total } \\
\text { Water } \\
\text { Sellers }\end{array}$ \\
\hline Respondents & 69 & 312 & 50 & 158 & 520 \\
\hline Reduce debt & $28 \%$ & $36 \%$ & $32 \%$ & $15 \%$ & $29 \%$ \\
\hline $\begin{array}{l}\text { Improve farm } \\
\text { income, viability }\end{array}$ & $26 \%$ & $23 \%$ & $22 \%$ & $19 \%$ & $21 \%$ \\
\hline $\begin{array}{l}\text { On farm } \\
\text { investment }\end{array}$ & $3 \%$ & $10 \%$ & $6 \%$ & $4 \%$ & $8 \%$ \\
\hline Exiting farming & $16 \%$ & $4 \%$ & $16 \%$ & $38 \%$ & $16 \%$ \\
\hline Surplus water & $7 \%$ & $13 \%$ & $2 \%$ & $6 \%$ & $10 \%$ \\
\hline Age & $6 \%$ & $3 \%$ & $6 \%$ & $6 \%$ & $4 \%$ \\
\hline Death or divorce & $3 \%$ & $2 \%$ & $0 \%$ & $5 \%$ & $3 \%$ \\
\hline Other & $12 \%$ & $9 \%$ & $16 \%$ & $6 \%$ & $9 \%$ \\
\hline
\end{tabular}


still farming naming it as the main reason. $8 \%$ of respondents who sold water did so to invest the returns on the farm, such as more efficient infrastructure. Hence, up to $20 \%$ of water entitlement sales should not have had on-farm. Around $20 \%$ of farmers were choosing to exit farming in one way or another, as a result of age, retirement, career change, divorce or death.

Considering the percentage of farms that may face troubles in the future from selling water, it may be up to $60 \%$ (given that $20 \%$ exited and $20 \%$ reported surplus water or on-farm investment as reasons for sale) of those who sold water. The question is, how many of these will face future farming challenges with the advent of drought? To answer this question, we need to consider water use by irrigators in the MDB, historical, current and predicted allocations and future climate change impacts.

\section{Water use across the Basin}

\subsection{Data collection}

Data was collected from the Murray-Darling Basin Authority's (MDBA) water audit monitoring series 1994-95 to 2010-11. These data included details on irrigation diversions, entitlements, trade, allocations and water use by MDB regions and states (we only collected data for New South Wales (NSW), Victoria and SA). We also drew on water use data collected from a number of historical irrigator surveys undertaken by researchers from the University of South Australia (UniSA). This survey data included surveys conducted in the Goulburn-Murray Irrigation District in 1998-99, 2008-09, 2010-11 and 201112; the NSW Murray and Murrumbidgee regions in 2010-11 and 2011-12; and the SA Murray region in 2008-09, 2010-11 and 2011-12. Wheeler et al. [8] provide more detail.

\section{Results and discussion}

Figure 1 presents a graphical representation of historic water use across the MDB. It shows that, over time, the percentage of water allocated from entitlements fell from $120 \%$ in $1996-97$ to $29 \%$ in $2008-09$, before increasing again to almost $80 \%$ in 2011 . As a percentage of water used, it generally follows the opposite direction to the percentage of water allocated from entitlements. When water is plentiful, rainfall is high, and allocations are high, generally the percentage of allocation water use is lower. Conversely, when allocations are low, irrigators generally use much more of the water allocations they receive. Figure 1 also provides a comparison of UniSA survey data on water use percentages over four years from 1998-99 to 2010-11. It shows that UniSA's survey data on the mean individual irrigator water use is remarkably similar to that for the whole Basin. The exception is 1998-99, where our survey results indicate mean water use of $86 \%$ by farmers, where as the regional mean was $65 \%$. Similarly, UniSA survey data underestimated average water use in 2010 11 , and slightly overestimated it in 2011-12. Nevertheless, the differences are 
not overtly large, and provide strong support for any further analysis that uses survey water use data and farmers recall of water use to represent what may happen to farmers from a sale of water entitlements. On average, UniSA historical data suggests that over the past five years, farmers in the southern MDB used $49 \%$ of the water allocated to them.

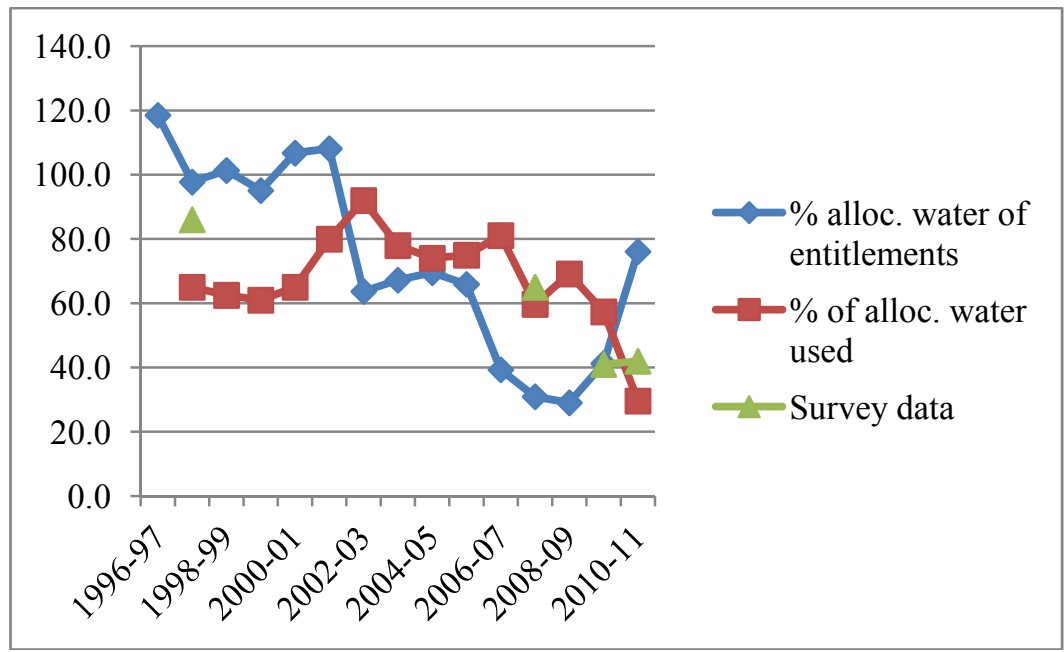

Figure 1: Water use and allocations in the MDB. Sources: MDBA Water Audit Monitoring Reports (various years) and UniSA historical irrigator surveys.

These figures are representative of: i) regional water use in the MDB; and ii) surveys of representative irrigation regions in the southern MDB. What they do not reflect is the water use of irrigators that have sold water entitlements. Cheesman and Wheeler [1] asked 520 irrigators selling water entitlement to the Restoring the Balance program: "Before you first sold water to the Commonwealth, on average (such as the previous five years) how much of your water entitlements allocated to you did you use?" For farmers that had sold water in 2008-09, their mean water use was $80 \%$; for those who sold water in 2009-10 it was 75\%; and for those that had sold water in $2010-11$ it was $70 \%$. These results reflect that i) those irrigators selling water may have much higher water use in general; and ii) mean water use is impacted by time, climate conditions and water allocations in general. The mean water use proportion in 2010-11 reported by irrigators who had sold water to the Restoring the Balance program and were still farming in 2011-12 was 50\%, which is greater than UniSA's estimate of $41 \%$ in $2010-11$. It therefore seems to be the case that those irrigators who have sold water use more of their water than other irrigators, perhaps $10 \%$ more.

Wheeler et al. [8] provide more insight into the differences between water sellers and non-sellers. They profiled irrigators in 2008-09 and 2010-11 who 
i) were thinking of selling water entitlements to the government; and ii) had actually sold their water. In the willingness to sell water models, they found:

- Irrigators are less willing to sell water to the government if they were more succession and tradition orientated, indicating the importance of needing water for the family and the business to continue farming. On the other hand, there was evidence in 2008-09 that farmers are more willing to sell water if they are more commercially oriented, and those more environmentally orientated were more likely to be willing to sell water in 2010-11.

- $\quad$ Male irrigators were slightly more willing to sell water in 2008-09, while those who have worked fewer years on a farm are more willing to sell water.

- Irrigators who used government agencies as their main source of information were more likely to be thinking about selling water in 200809.

- $\quad$ Farm income is inversely related to the willingness to sell water across both years. Similarly, the more full-time employees on the farm in 201011 , the less likely the irrigator is thinking about selling water. Although debt was found to be positively related to the willingness to sell water in some state models, no such evidence was found in the restricted southern MDB models.

- $\quad$ The larger the high security water entitlements owned by irrigators, the more likely they were to want to sell water across both years.

- The results in 2010-11 found that an increase in total farm size was positively associated with an increase in willingness to sell water. In 2008-09, an increase in the percentage of those farms producing horticultural products was negatively associated with willingness to sell, while in 2010-11 it was positively associated with those thinking about selling water.

- In 2010-11 net sellers of allocation water in the past were more likely to be willing to sell water entitlements, and irrigators who sold water entitlements in the past are more likely to be thinking about selling water to the government.

- $\quad$ Higher mean water allocations at the end of the season in the past five years was associated with less willingness to sell water, and less water sold.

- $\quad$ The existence of a cap (or a ballot), increased irrigators willingness to sell water in the future, but it had no impact on who had actually sold their water.

In the actual water sales models, it was found that irrigators were more likely to have sold water, if they: i) had higher farm debt, ii) had smaller high security water entitlements, iii) had lower farm incomes, iv) had a higher number of children, v) had lower education levels, vi) had a whole farm plan, vii) had used government agencies as a source of information, viii) had a smaller percentage of 
the property under permanent horticulture, ix) had a smaller percentage of the property under annual crops, $\mathrm{x}$ ) were less orientated towards traditional farming attitudes, xi) lived in SA, xii) were younger, xiii) had been a net seller of water allocations in the past, xiv) had better health, and xv) had a lower mean annual water allocation in the past five years.

Wheeler et al. [8] concluded that farm financial factors seem to be relatively more important in the ex-post models, while regional and institutional factors, although important in the ex-post models, seem to have the most influence in the ex-ante models. Importantly, what these results highlight is that those who own more water entitlements (especially general and low securities) are more likely to be considering selling some of their water entitlements. However, actual sales of water have occurred with irrigators who own relatively smaller water entitlements. We also know from Wheeler et al. [8] that the smaller the entitlement owned, the more likely it is that irrigators will sell all of it and exit the industry.

\subsection{Mean water entitlement sold from total water entitlements owned}

Cheesman and Wheeler [1] found that the mean amount of water entitlement sold varied. Irrigators can hold many different entitlements to water, such as high, general, and low surface water entitlements, as well as stock, domestic. and groundwater entitlements. Hence, any calculation of how much water entitlements irrigators are likely to sell must take into consideration all their water holdings. Irrigators who stated that they sold all of at least one surface water entitlement, but were still farming, sold on average $84 \%$ of their entire water holdings to government. On the other hand, those who sold only part of their surface water entitlements, and stayed farming, sold on average $44 \%$ of their water holdings. Altogether for those remaining in farming, the mean proportion sold was $50 \%$.

UniSA historical data on water sellers (for 2008-09 and 2010-11) suggests that those who sold water and stayed in farming, sold on average $42 \%$ of their water entitlements. On the other hand, those who were thinking of selling water entitlements planned to sell up to $55 \%$ of their water entitlements. The closeness of these two different datasets provides validity and support for their results, that irrigators who want to stay in farming sell half, or less than half, of their holdings.

\subsection{Future water availability}

Table 2 illustrates the percentage of entitlements allocated at the end of each season in the MDB over the past 12 years. The last two rows are the LTAAY, represented by that type of water security in that region, and a very rough estimate of the predicted changes that may occur to the LTAAY from future climate change. The LTAAY is important for many reasons. One key reason is that it is used by the Australian Department of Sustainability, Environment, Populations and Communities (DSEWPaC) to estimate how much water is 


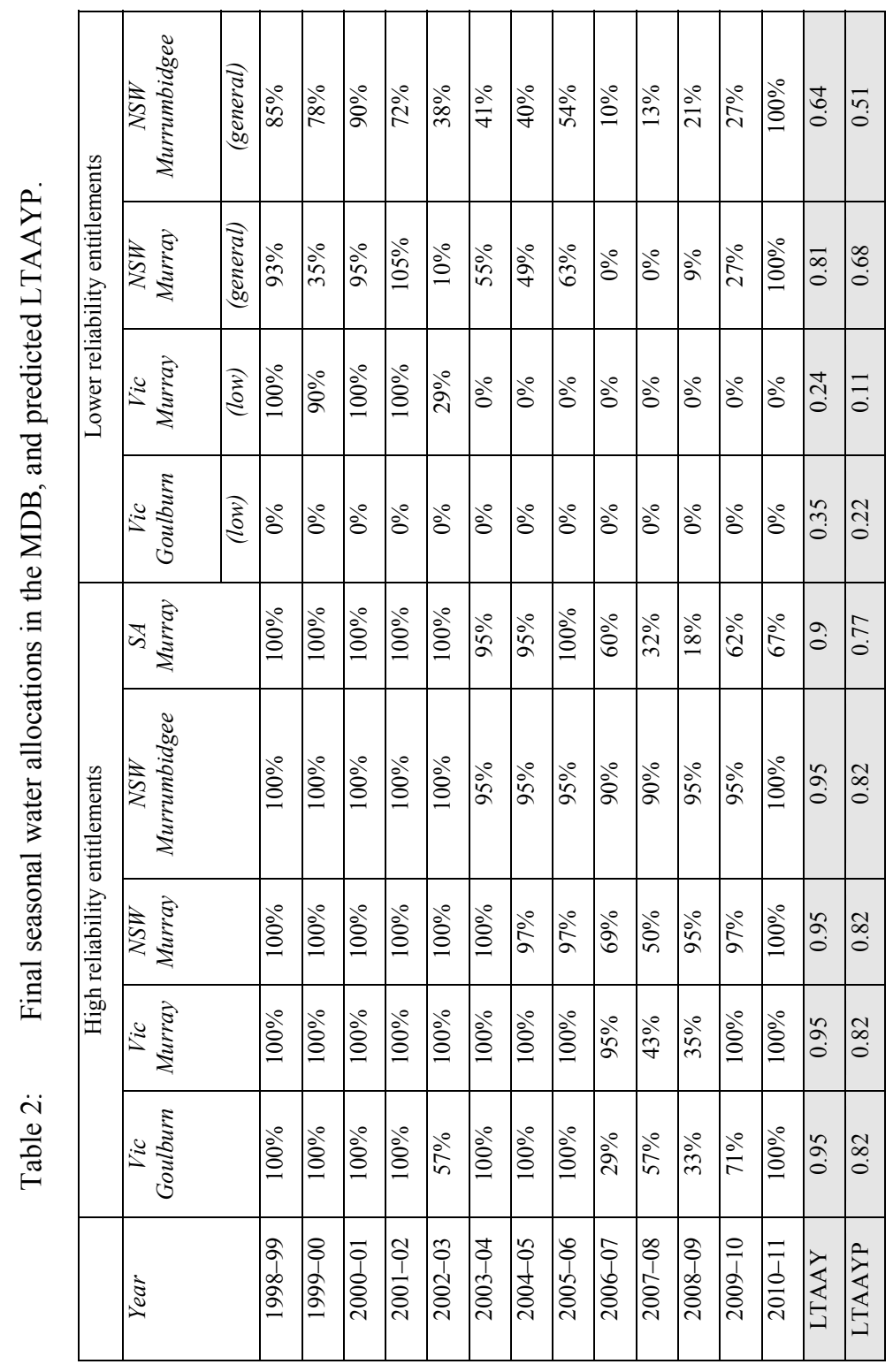


attached on average to any regional water entitlement they purchase. The Commonwealth Scientific and Industrial Research Organisation (CSIRO) [9] predicted a median $13 \%$ decline in water availability in the southern MDB, and the LTAAYP (long-term average annual yield predicted) is a simple extrapolation of this decline. Another key message from this table is that over the past decade, there has not been any year that represents the LTAAY figure, the years that come close are 1998-99 and 2001-02, hence just how representative the LTAAY estimates are may be questionable. Indeed, DSEWPaC did downgrade the LTAAY figures at one point, before being forced by farming organisations to return to the current estimates. In terms of the LTAAYP, 200506 is the year most likely to represent an 'average' year we can expect in the future.

\subsection{Sustainability issues associated with selling water}

This paper aims to identify sustainability issues that may be associated with irrigators selling water entitlements while continuing to farm. This section addresses that issue using information from UniSA's historical surveys over the past five years.

From the information outlined in this paper, we know that on average southern MDB irrigators who are planning to continue farming sold $42-44 \%$ of their water entitlements. Hence, irrigators had on average $56-58 \%$ of their available water entitlements left. We also know that on average southern MDB irrigators used $49-58 \%$ of their available water (note: the calculation of this figure is dependent upon the regional allocations). Therefore, it seems that irrigators who have sold to the Australian Government on average have sold all their surplus water. Selling water therefore should have no impact on the average irrigator in the southern MDB, when water is plentiful. Results by Cheesman and Wheeler [1] support this, with $50 \%$ of the 312 irrigators who stayed farming reporting no farm production consequences from selling water.

Hence, on average, irrigators who sold water eliminated their surplus water. Over the last five year period in Table 2, mean allocations for high security entitlements were $71 \%$ (ranging from $47 \%$ in SA to $94 \%$ in NSW). This is the basis under which irrigators sold water. Therefore, in the future, if allocations are to drop below $71 \%$, then that is when an average irrigator who sold water may encounter problems. If the last decade is representative of the next decade, we predict that irrigators who sold water may be facing water shortages in three years out of ten. If we allow for a $13 \%$ decline in water availability due to climate change [9], then nearly four years out of ten they may be facing water shortages, without making any other changes. It is important to note that there are still many strategies farmers could employ to increase water efficiency (e.g. adopting more efficient irrigation infrastructure, changing water management activities, changing crop mixes, switching to dryland etc.). This needs further investigation.

Overall, it seems that the average irrigator has sold surplus water, and used the money to pay down debt, or to improve the viability of the farm. If they had not sold water, some may have been forced to leave farming. Hence, it has to be 
concluded that selling water to the Government has been of net benefit for the irrigator who chooses and/or wants to stay in farming, although future climate change suggests that they will have to adapt some of their farm management and water use practices, in order to not experience any detrimental effects from selling water. Considering that most have retained their delivery rights, those who have sold all their water entitlements have still maintained the ability to secure a future water supply. Irrigators did so to keep buying water allocations, and to perhaps buy back water entitlements in the future, and for farm value resale reasons.

\section{Conclusions}

The consequences of the buyback of water entitlements in the MDB have caused significant debate in Australia. By 2012 up to 20\% of all irrigators had sold water to the Federal Government's Restoring the Balance program, with at least $10 \%$ more irrigators having tried to. Although there has been a number of economic and social studies have considered the impact of the buyback for the economy, there has been little analysis focusing specifically on the future consequences that it may entail for individual irrigators. This paper has used a variety of data to provide a first step analysis on the question about the impact selling water has on irrigators.

Taking into account information on the fraction of water entitlements sold by southern MDB irrigators, their water use average, and regional allocations over the past five years, our findings suggest that farmers have eliminated their surplus water by selling. This suggests that if they do not make any further water management or farm changes (which many have done and will do), they will face water shortages potentially three in every ten years, and with the advent of climate change, four in every ten years. Of course, it is important to note that this is an overall analysis only, and the consequences of selling water will be different for each irrigator. Further long-term studies are required.

\section{References}

[1] Cheesman, J. and Wheeler, S., Survey of water entitlement sellers under the Restoring the Balance in the Murray-Darling Basin program, Final report prepared for the Department of Sustainability, Environment, Water, Population and Communities. Marsden Jacob Associates: Canberra, 2012.

[2] Department of Sustainability, Environment, Populations and Communities (DSEWPaC). Progress of water recovery to date under the Restoring the Balance in the Murray-Darling basin program Web Site, http://www.environment.gov.au/water/policy-programs/entitlementpurchasing/progress.html

[3] Australian Bureau of Statistics (ABS). Water Use on Australian Farms, 2010-11, Canberra, 2012.

[4] Australian Parliament. Of drought and flooding rains: Inquiry into the impact of the Guide to the Murray-Darling Basin Plan, House of 
Representatives Standing Committee on Regional Australia: Canberra, 2011.

[5] Morrison, M., Wheeler, S. and Hatton-MacDonald, D., Towards a more nuanced discussion of the net benefits of sharing water in the MurrayDarling Basin. Australian Farm Business Management Journal, 8(2), pp. 27-38, 2011.

[6] Dixon, P.B., Rimmer, M.T. and Wittwer, G., Saving the Southern MurrayDarling Basin: the Economic Effects of a Buyback of Irrigation Water. The Economic Record, 87(276), pp. 153-168, 2011.

[7] Bjornlund, H., Wheeler, S. and Cheesman, J., Irrigators, water trading, the environment, and debt: Perspectives and realities of buying water entitlements for the environment. Basin Futures: Water reform in the Murray-Darling Basin, eds. Q. Grafton and D. Connell, Australia National University Press: Canberra, pp. 291-302, 2011.

[8] Wheeler, S., Zuo, A., Bjornlund, H. and Lane-Miller, C., Selling the farm silver? Understanding water sales to the Australian government. Environmental and Resource Economics, 52(1), pp. 133-154, 2012.

[9] Commonwealth Scientific and Industrial Research Organisation (CSIRO). Water availability in the Murray-Darling Basin. A report to the Australian Government from the CSIRO Murray-Darling Basin Sustainable Yields Project. CSIRO: Melbourne, 2008. 